\title{
Influence of Plant Growth Regulators on Management of Barley Powdery Mildew under Salinity Stress
}

M.G. El-Samman

Plant Pathol. Dept., Fac. Agric., Ain shams Univ., Cairo, Egypt.

\begin{abstract}
The effect of plant growth regulators on barley powdery mildew caused by Blumeria graminis f.sp. hordei, under the influence of salinity, was conducted on two cultivars (Giza 123 and 126) in sand culture experiment. Plants were treated either by $10 \mathrm{ppm}$ abscisic acid $(\mathrm{ABA})$ or 25 and $50 \mathrm{ppm}$ paclobutrazol (PBZ) as foliar spray, 3 weeks after sowing. Four levels of $\mathrm{NaCl}$, i.e. $0,50,100$, and $200 \mathrm{mM}$, were applied as soil treatment two days after spraying plant growth regulators. Disease severity and area under disease progress curve (AUDPC) were estimated on the leaves, at different intervals, during the experiment. Obtained data demonstrated that $\mathrm{NaCl}$ led to suppression of powdery mildew disease and had a harmful effect on plant growth parameters. Disease severity and AUDPC values were found to be higher in untreated control than in case of treatment by $\mathrm{NaCl}$, plant growth regulators and their combinations. Treatments with $\mathrm{PBZ}$ and $\mathrm{ABA}$ significantly reduced powdery mildew severity on both cultivars and improved plant growth parameters (plant height, fresh and dry weight as well as grains yield) with increasing total chlorophyll content compared to the untreated control.
\end{abstract}

Keywords: Barley, disease severity, plant growth regulators, powdery mildew and salinity stress.

Powdery mildew is one of most destructive fungal diseases on barley (Hordeum vulgare L.). It caused by the biotrophic fungus Blumeria graminis f.sp. hordei, in temperate latitudes worldwide (Collins et al., 2002). The disease leads to a decrease in the yield and its quality (Noir et al., 2009). Barley is a salt-tolerant crop widely grown in the arid and semiarid regions of the Mediterranean for forage purposes and as a grain crop (Al-Karaki, 2001). Several workers used $\mathrm{NaCl}$ to suppress plant diseases (Eisa et al., 2000; Elmer, 2003 and Achuo et al., 2006). Eisa et al. (2000) indicated that infection of sugar beet by Erysiphe betae was reduced when the plants treated with $\mathrm{NaCl}$ compared to untreated.

Salinity is one of major obstacle to increase crop productivity and the most severe a biotic stress factors and today as more 800 million ha of land are salt affected on area equivalent $6 \%$ of the world (Munns, 2002), and about one-third of the world's irrigated land suffers from secondary-induced salinization (Flowers and Yeo, 1995). Tavakkoli et al. (2011) showed that growing barley under $\mathrm{NaCl}$ stress reduced the growth of barley in hydroponics and in soil with significant differences among genotypes toward the salt stress. The role of plant growth regulators (PGRs) in development of plant disease was studied by many researchers (Edwards, 1983; Michiewcz, 1987 and Al-Masri et al., 2002). Alteration in the level of PGRs in 
disease susceptibility or resistance reaction is associated with plant pathogen interaction (Singh et al., 1997). Abscisic acid (ABA) plays very important role in many aspects of plant development in the regulation of stomatal aperture and in the initiation of adaptive responses to various environmental conditions. Adaptation to drought, low temperature and salinity is regulated by the combinatorial activity of interconnected ABA-dependent and ABA-independent signalling pathways (Giraudat et al., 1994 and Thaler and Bostock, 2004). ABA has multirole in disease resistance, where several studies reported the acquirement of plant resistance against pathogen by ABA (Ton et al., 2009 and Cao et al., 2011). Paclobutrazol (PBZ) is one of triazole compounds, a widely used as growth retardant, induces mild stress tolerance in seedlings and adult plants. More specifically, PBZ has been reported to protect the plants against drought stress (Fletcher et al., 2000). In addition PBS and ABA treatment increased the chlorophyll content of barley plants (El-Shamey, 2008).

The purpose of this study was to evaluate the effect of plant growth regulators as a foliar application on salinity stress and on the development of powdery mildew and growth parameters of barley plants.

\section{Materials and Methods}

Pots $(30 \mathrm{~cm}$ diameter) were filled with washed sand $(10 \mathrm{~kg}$ sand/pot). Five barely grains from each of tested cultivars, i.e. Giza 123 and Giza 126, obtained from the Wheat Res. Dept., Crop Res. Inst., Egypt, were sown in each pot (with bottom drainage) in November 2010. Pots were irrigated with tap water for the first three weeks, and then seedlings were thinned into two plants per pot. Three weeks after sowing, aqueous solutions of 25 and 50 ppm PBZ, 10 ppm ABA and tap water (Control) were foliar sprayed on plants using hand air compressed atomizer. Two days after growth regulators had been treated, the salt treatments $(\mathrm{NaCl})$ were added to the water of irrigation. Pots were arranged in complete randomize design with ten replicates for each particular treatment. Each plant growth regulator treatment included four salinity levels, i.e. tap water (control), 50, 100, and $200 \mathrm{mM} \mathrm{NaCl}$. Pots were amended with nutrients according to Arnon and hoagland (1940). The irrigation with the nutrient solution started two weeks after sowing and till three weeks before harvest

Inoculation and disease assessment:

The inoculation was carried out when plants reached four weeks old by shaking or brushing conidia from diseased plants on the grown plants under study. Ten days after of incubation, disease reaction was scored. This scoring was done according to a scale ranging from 0-9 according to Mastebroek et al. (1995). Disease severity (DS) was estimated four times during the growth period as the percentage of leaves covered by the pathogen to calculate AUDPC. The percentage of disease severity was calculated by using the following formula of Wheeler (1969):

Disease severity $(\%)=\sum(\mathrm{f}$ X v)/nx X 100 
Whereas: $f=$ Frequency of a numerical rating; $v=$ Numerical rating scale (1-5); $\mathrm{n}=$ Total number of tested plants and $\mathrm{x}=$ maximal value (5) of the evaluation scale.

For each cultivar and each treatment, AUDPC was calculated to summarize progress of the disease according to the following formula of Shaner and Finney (1977):

$$
\text { AUDPC }=\operatorname{\Sigma in}-1[(y i+y i+1) / 2](t i+1-t i)
$$

Whereas: $n=$ Number of disease assessment times; $y=$ Disease severity and $t=$ time duration of the epidemic.

Chlorophyll content:

Plant height $(\mathrm{cm})$, fresh and dry weight/plant $(\mathrm{g})$ was determined 40 days after inoculation from five plants for each treatment. When the plants had reached maturity the spikes were harvested and threshed to determine the weight of the 100 grains in each treatment.

Statistical analysis:

Data were statistically analyzed by analysis of variance (ANOVA) using the statistical analysis system (SAS) software (Littell et al., 1996). Means were separated by Fisher's protected least significant differences (LSD) at P $₫$ ).05.

\section{Res u I t s}

Data presented in Table (1) clearly show that artificial inoculation of both tested barley cultivars with Blumeria graminis f.sp. hordei caused powdery mildew symptoms. Disease severity percentage of cv. Giza 123 higher than that of cv. Giza 126, being 33.3 and 29.25, respectively. The percentages of infection of plants treated with ABA (10 ppm) and PBZ (25 and $50 \mathrm{ppm})$ were 22.2, 19.25 and $16.25 \%$ for cv. Giza 123 and 29.29, 23.33 and $15.18 \%$ for cv. Giza 126, respectively. Data show also that increasing $\mathrm{NaCl}$ concentration $(50,100$ and $200 \mathrm{mM}$ ) without PGRs treatment, significantly reduced powdery mildew being 22.9, 4.40 and zero for cv. Giza 123 and 22.86, 15.18 and $11.11 \%$ for cv. Giza 126. The highest effect of $\mathrm{NaCl}$ and PGRs on the disease was recorded with $\mathrm{NaCl}(50$ and $100 \mathrm{mM})$, where it exhibited significant reduction to the disease severity compared to untreated control. ABA (10 ppm) caused lowest effect on reducing the disease severity (Table 1). Mean PBZ (50 ppm) was the most effective one on disease severity, followed by PBZ (25 ppm). The reduction in disease severity was evident from calculated AUDPC value. AUDPC value for powdery mildew development was calculated for each tested cultivar and treatment and statistically analyzed to determine the significant differences among the treatment (Fig. 1).

Also, results indicate that there was significant difference in the AUDPC among the concentration of $\mathrm{NaCl}, \mathrm{ABA}$ and $\mathrm{PBZ}$ for both cultivars. In addition the increase in $\mathrm{NaCl}$ concentration decreased plant height, fresh and dry weight and the yield of both tested cultivars (Table 2). 
Table 1. Effect of spraying barley cvs. Giza 123 and 126 with two plant growth regulators on of the severity of powdery mildew under the influence of salinity

\begin{tabular}{|c|c|c|c|c|c|c|}
\hline \multirow{2}{*}{\multicolumn{3}{|c|}{ Treatment }} & \multicolumn{4}{|c|}{ Cultivar } \\
\hline & & & \multicolumn{2}{|c|}{ Giza123 } & \multicolumn{2}{|c|}{ Giza126 } \\
\hline \multicolumn{2}{|c|}{$\begin{array}{l}\text { PGRs } \\
(\mathrm{ppm})\end{array}$} & $\begin{array}{l}\mathrm{NaCl} \\
(\mathrm{mM})\end{array}$ & $\begin{array}{c}\text { Disease } * \\
\text { severity }(\%)\end{array}$ & $\begin{array}{c}\text { Reduction } \\
(\%)\end{array}$ & $\begin{array}{c}\text { Disease } \\
\text { severity }(\%)\end{array}$ & $\begin{array}{l}\text { Reduction } \\
(\%)\end{array}$ \\
\hline Control & 0.0 & 0.0 & $33.0 * *$ & --- & 29.25 & ---- \\
\hline $\mathrm{ABA}$ & 10 & 0.0 & 22.20 & 23.3 & 29.25 & 0.0 \\
\hline PBZ & 25 & 0.0 & 19.25 & 42.19 & 23.33 & 20.23 \\
\hline PBZ & 50 & 0.0 & 16.29 & 51.17 & 15.18 & 46.05 \\
\hline Contro & 0.0 & 50 & 22.90 & 21.23 & 22.86 & 21.85 \\
\hline $\mathrm{ABA}$ & 10 & 50 & 18.80 & 43.54 & 11.85 & 59.48 \\
\hline PBZ & 25 & 50 & 15.50 & 52.40 & 11.85 & 60.75 \\
\hline PBZ & 50 & 50 & 11.48 & 65.52 & 7.70 & 73.67 \\
\hline Control & 0.0 & 100 & 4.40 & 86.78 & 15.18 & 48.10 \\
\hline $\mathrm{ABA}$ & 10 & 100 & 3.70 & 88.88 & 8.51 & 70.90 \\
\hline PBZ & 25 & 100 & 4.07 & 87.77 & 7.40 & 74.70 \\
\hline PBZ & 50 & 100 & 0.0 & 0.0 & 3.70 & 87.35 \\
\hline Control & 0.0 & 200 & 0.0 & 0.0 & 11.11 & 62.01 \\
\hline $\mathrm{ABA}$ & 10 & 200 & 0.0 & 0.0 & 03.70 & 87.35 \\
\hline PBZ & 25 & 200 & 0.0 & 0.0 & 0.0 & 0.0 \\
\hline PBZ & 50 & 200 & 0.0 & 0.0 & 0.0 & 0.0 \\
\hline L.S.D. & $5 \%$ & $\begin{array}{ll}--- \\
\end{array}$ & 1.78 & ---- & 1.61 & ---- \\
\hline
\end{tabular}

* Disease severity was recorded 40 day after inoculation.

** Average of 5 replicates.

Table 2. Effect of plant growth regulators on plant height $(\mathrm{cm})$, fresh and dry weight (g) and weight of hundred grains of cvs. Giza 123 and 126, greenhouse experiment

\begin{tabular}{|c|c|c|c|c|c|c|c|c|c|}
\hline \multirow{2}{*}{$\begin{array}{l}\text { PGRs } \\
\text { (ppm) }\end{array}$} & \multirow{2}{*}{$\begin{array}{c}\mathrm{NaCl} \\
\mathrm{mM}\end{array}$} & \multicolumn{2}{|c|}{$\begin{array}{l}\text { Plant height } \\
(\mathrm{cm})\end{array}$} & \multicolumn{2}{|c|}{$\begin{array}{c}\text { Fresh weigh } \\
(\mathrm{g})\end{array}$} & \multicolumn{2}{|c|}{$\begin{array}{c}\text { Dry weight } \\
(\mathrm{g})\end{array}$} & \multicolumn{2}{|c|}{$\begin{array}{l}\text { Weight of } 100 \\
\text { grain }(\mathrm{g})\end{array}$} \\
\hline & & Giza 123 & Giza 126 & Giza 123 & Giza 126 & Giza 123 & Giza 126 & Giza 123 & Giza 126 \\
\hline ABA10 & 0 & 106 & 118 & 28.4 & 44.5 & 18.7 & 32.0 & 4.20 & 4.9 \\
\hline PBZ25 & 0 & 91 & 98 & 20.0 & 52.6 & 15.6 & 48.0 & 3.32 & 4.6 \\
\hline PBZ50 & 0 & 87 & 97 & 19.4 & 42.2 & 14.0 & 37.1 & 3.14 & 3.6 \\
\hline 0.0 & 50 & 92 & 94 & 11.0 & 17.5 & 7.7 & 15.0 & 2.3 & 2.6 \\
\hline ABA10 & 50 & 100 & 93 & 11.5 & 19.0 & 7.0 & 16.0 & 3.0 & 3.4 \\
\hline PBZ25 & 50 & 91 & 92 & 13.2 & 20.0 & 8.5 & 17.0 & 3.1 & 5.4 \\
\hline PB250 & 50 & 57 & 73 & 13.8 & 19.0 & 100 & 17.2 & 2.6 & 9.2 \\
\hline 0.0 & 100 & 57 & 82 & 8.6 & 6.0 & 6.0 & 4.8 & 1.9 & 1.6 \\
\hline ABA10 & 100 & 84 & 90 & 12.2 & 9.4 & 9.5 & 8.0 & 1.8 & 2.2 \\
\hline PBZ25 & 100 & 89 & 90 & 12.6 & 19.0 & 11.0 & 17.0 & 2.2 & 2.4 \\
\hline PBZ50 & 100 & 75 & 85 & 12.0 & 16.0 & 8.0 & 15.0 & 1.3 & 1.8 \\
\hline 0.0 & 200 & 64 & 61 & 2.6 & 3.0 & 1.6 & 1.8 & 0.4 & 0.4 \\
\hline ABA10 & 200 & 71 & 77 & 2.8 & 11.8 & 1.5 & 9.1 & 0.5 & 0.6 \\
\hline PBZ25 & 200 & 81 & 80 & 2.8 & 10.0 & 2.0 & 7.0 & 0.8 & 0.9 \\
\hline PBZ50 & 200 & 65 & 67 & 2.7 & 7.0 & 1.9 & 6.5 & 0.7 & 0.8 \\
\hline \multicolumn{2}{|c|}{ Control } & 105 & 98 & 35.6 & 36.5 & 29.3 & 28.1 & 3.10 & 3.3 \\
\hline \multicolumn{2}{|c|}{ L.S.D at $5 \%$} & 9.4 & 8.9 & 3.1 & 3.8 & 1.09 & 1.3 & 0.4 & 0.4 \\
\hline
\end{tabular}




\section{C.V. Giza 126}

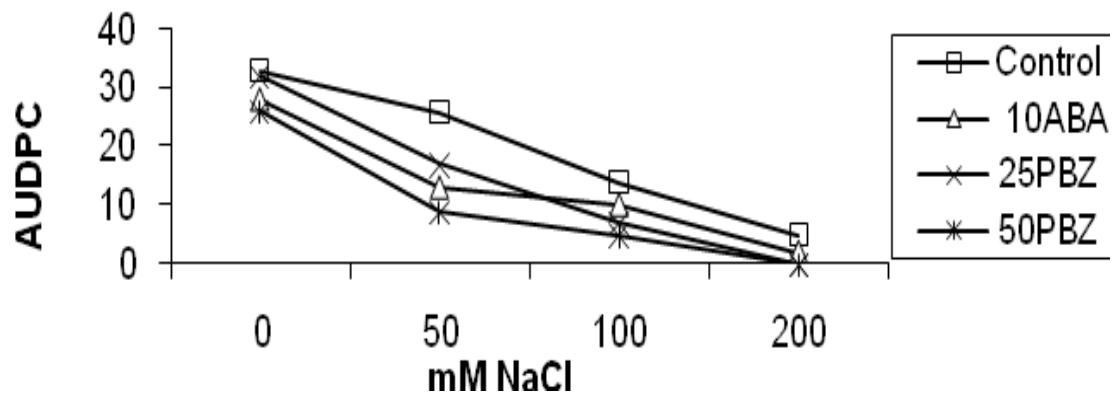

C.V Giza 123

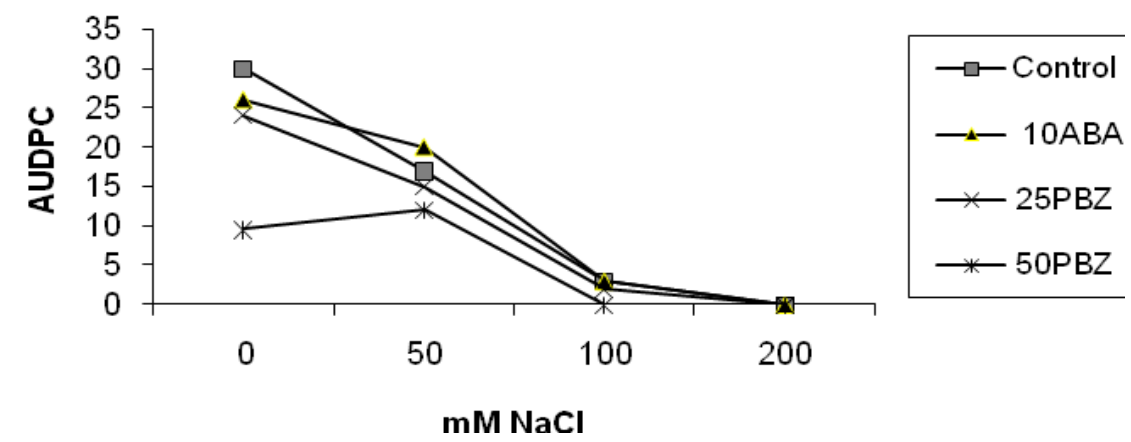

Fig. 1. Effect of different concentrations of $\mathrm{NaCl}$ and their combination with plant growth regulators on AUDPC of powdery mildew on cvs. Giza 123 and Giza 126.

Total chlorophyll content of the two tested cultivars showed significant decrease under salinity stress, especially at 100 and $200 \mathrm{mM}$ (Table 3). PBZ treatment was more effective in increasing total chlorophyll content, being 2.62 and $2.51 \mathrm{mg} / \mathrm{g}$ fresh weight with 25 and $50 \mathrm{ppm}$ when $50 \mathrm{mM} \mathrm{NaCl}$ was used on cv. Giza 126 , while it gave the least amount of chlorophyll in case of $\mathrm{NaCl} 200 \mathrm{mM}$. Untreated control recorded 0.77 and $0.73 \mathrm{mg} / \mathrm{g}$ fresh weight of cv. Giza 123 and Giza 126, respectively.

Egypt. J. Phytopathol., Vol. 41, No. 2 (2013) 
Table 3. Effect of plant growth regulators as foliar treatment, NaCl concentration and their combination on total chlorophyll content (mg/g fresh weight) of cvs. Giza 123 and 126

\begin{tabular}{|c|c|c|c|c|c|c|c|c|}
\hline \multirow{3}{*}{$\begin{array}{l}\text { Conc. } \\
\mathrm{NaCl} \\
(\mathrm{mM})\end{array}$} & \multicolumn{4}{|c|}{ Giza123 } & \multicolumn{4}{|c|}{ Giza 126} \\
\hline & \multirow{2}{*}{ Control } & \multirow{2}{*}{$\begin{array}{c}\mathrm{ABA}^{*} \\
10\end{array}$} & \multicolumn{2}{|c|}{$\mathrm{PBZ}^{* *}$} & \multirow{2}{*}{ Control } & \multirow{2}{*}{$\begin{array}{c}\mathrm{ABA}^{*} \\
10\end{array}$} & \multicolumn{2}{|c|}{ PBZ** } \\
\hline & & & 25 & 50 & & & 25 & 50 \\
\hline 0 & 1.84 & 1.85 & 1.99 & 2.20 & 2.16 & 2.01 & 2.23 & 2.40 \\
\hline 50 & 1.46 & 1.50 & 1.73 & 1.62 & 2.06 & 2.33 & 2.62 & 2.51 \\
\hline 100 & 0.87 & 1.50 & 1.63 & 1.52 & 1.82 & 1.98 & 2.52 & 1.83 \\
\hline 200 & 0.77 & 1.20 & 1.28 & 1.32 & 0.73 & 1.02 & 1.40 & 1.62 \\
\hline \multicolumn{2}{|c|}{ L.S.D at 0.05} & \multicolumn{4}{|c|}{0.21} & \multicolumn{3}{|c|}{0.29} \\
\hline
\end{tabular}

* Abscisic acid (ABA 10 ppm).

** Paclobutrazol (PBZ 25.5 ppm).

\section{D i s c u s s i o n}

The need to produce cereal cultivars tolerate salinity with disease resistance has been recognized as an important criterion in many cereal crops, especially the reduction of plant growth under salinity stress is a common phenomenon with increasing saline land in the world. The results obtained in this study clearly demonstrated that Blumeria graminis f.sp. hordei, able to infect both tested cvs. Giza 123 and 126 causing powdery mildew symptoms, but failed to do this when the plants exposed to the higher concentration of saline. The AUDPC was higher for cv. Giza 123 than cv. Giza 126 and this phenomenon may be attributed to the difference of genetic behaviour of both cultivars (Dreiseitl, 2007). The decrease in powdery mildew severity under salinity stress agreed with reported by Eisa et al. (2000). Some authors reported that $\mathrm{NaCl}$ lead to suppress of other diseases (Hopkins, 1985 and Elmer, 2003). The obtained results showed that plant growth regulators can overcome salinity problem. These results are in agreement with results reported by Achuo et al. (2006) and El-Shamey (2008) as they were used plant growth regulators as an antistress agent to improve salt tolerance. Results revealed, also that foliar spray by ABA and PBZ had lower AUDPC compared to untreated control. Role of plant growth regulators (PGRs) in development of plant disease resistance have been studied also by Edwards (1983), Michiewcz (1987) and Al-Masri et al. (2002). ABA has multirole in disease resistance, where several studies reported the acquirement of resistance against pathogens due to ABA treatment (Ton et al., 2009 and Cao et al., 2011). There are reports of positive correlation between endogenous ABA levels and plant disease resistance (MauchMani and Mauch, 2005 and Achuo et al., 2006) via its positive effect on callus deposition or through its control of stomatal aperture and water relation. The results suggested that $\mathrm{NaCl}$ has damage effect on powdery mildew and on barley plants. PBZ reduced the plant height at $50 \mathrm{ppm}$, but the low concentration (25 ppm) increased the fresh and dry weight in addition to weight of the grains. PBZ (50 ppm) reduced the negative effects of increasing salinity on growth parameters and chlorophyll content. Chlorophyll content is one of many physiological processes that altered in plant grown in saline soil, which ultimately reduce their growth and yield. 
Parida and Das (2005) suggested that the decrease in chlorophyll content in response to salt stress is a general phenomenon, which referred to reduction of chlorophyll synthesis and appearing of chlorosis on plants.

Results obtained in this study indicated that the ability of plant growth regulators could be used as an efficient procedure to increase plant productivity and overcome of salinity disorders as well as control of powdery mildew.

\section{Ref e r e n c es}

Achuo, E.A.; Prinsen, E. and Höfte, M. 2006. Influence of drought, salt stress and abscisic acid on the resistance of tomato to Botrytis cinerea and Oidium neolycopesici. Plant Pathol., 55: 178-186.

Al-Masri, M.I.; Ali-Shtayeh, M. S.; Elad, Y.; Sharon A.; Tudzynski., P. and Barakat, R. 2002. Effect of plant growth regulators on white mould (Sclerotinia sclerotiorum) on bean and cucumber. J. Phytopathol., 150: 481-487.

Al-Karaki. G.N. 2001. Germination, sodium, and potassium concentrations of barley seeds as influenced by salinity. J. Plant Nutr., 24(3): 511-522.

Arnon, D.I. and Hoagland, D.R. 1940. Crop production in artificial solutions and soils with special references to factor influencing yields and absorption of inorganic nutrients. Soil Sci., 50: 430-435.

Cao, F.Y.; Yoshioka, K. and Desveaux, D. 2011. The role of ABA in plantpathogen interactions. J. Plant Res., 124: 489-499.

Collins, N.C.; Sadanandom, A. and Schulze-Lefert, P. 2002. Genes and molecular mechanisms controlling powdery mildew resistance in barley. Pages: 134-145. In: The Powdery Mildews. Bélanger, R.R.; Bushnell, W.R.; Dik, A.J. and Carver, L.W. (eds.). APS Press. St Paul, MM, USA.

Dreiseitl, A. 2007. Powdery mildew resistance in winter barley cultivars. Plant Breed., 126: 268- 273.

Edwards, H.H. 1983. Effect of kinetin, abscisic acid and cations on host-parasite relation of barley inoculated with Erysiphe graminis f.sp. hordei. J. Phytopathol., 107: 22-30.

Eisa, S.S.; Ali, S.H.; El-Samman, M.G. and El-Shamey, I.Z. 2000. Salinity induced biotolerance against powdery mildew of sugar beet. Ann. Agric. Sci. (Cairo), 4: 1421-1435. (Special Edition).

Elmer, W.H. 2003. Local and systemic effects of $\mathrm{NaCl}$ on root composition, Rhizobacteria, and Fusarium crown and root rot of asparagus. Phytopathology, 93: 186-192.

El-Shamey, I.Z. (2008). Counteraction of salt stressed barley on sandy soil by plant growth regulators. J. Agric. Sci., Mansoura Univ., 33(6): 4153-4162.

Fletcher, R.A.; Gilley, A.; Davis, T.D. and Sankhla, A.N. 2000. Triazoles as plant growth regulators and stress protectants. Hort. Rev., 24: 55-138.

Egypt. J. Phytopathol., Vol. 41, No. 2 (2013) 
Flowers, T.J. and Yeo, A.R. 1995. Breeding for salinity resistance in crop plants: Where next? Austral. J. Plant Physiol., 22: 875-884.

Giraudat, J.; Parcy, F.; Bertauche, N.; Gosti, F. and Leung, J. 1994. Current advances in abscisic acid action and signalling. Plant Mole. Biol., 26: 1557-77.

Hopkins, D.L., 1985. Effect of plant growth regulators on development Pierce's disease symptoms in grapevine. Plant Dis., 69: 944-946.

Littell, R.C.; Milliken, G.A.; Stroup, W.W. and Wolfinger, R.D. 1996. SAS System for Mixed Models. SAS Publications order \#55235. SAS Institute Inc., NC, USA.

Mastebroek, H.D; Bakema-Boomstra, A.G. and Gaj, M. 1995.Genetic analysis of powdery mildew resistance derived from wild barley (Hordeum vulgare f.sp. spontaneum). Plant Breed., 114: 121-125.

Mauch-Mani, B. and Mauch, F. 2005.The role of abscisic acid in plant-pathogen interactions. Current Opinion Plant Biol., 8(4): 409-414.

Michiewcz, M. 1987. Role of plant growth regulators in host-pathogen relationships. Biologia Plantarum, 29(4): 273-278.

Munns, R. 2002. Comparative physiology of salt and water stress. Plant Cell Environ., 25: 239-250.

Noir, S.; Colby, T.; Harzen, A.; Schmidt, J. and Panstruga, R. 2009. A proteomic analysis of powdery mildew (Blumeria graminis f.sp. hordei) conidiospores. Mole. Plant Pathol., 10( 2): 223-236.

Parida, A.K. and Das, A.B. 2005. Salt tolerance and salinity effects on plants. Ecotoxicol. Environ. Safety, 60(3): 324-349.

Singh, P.P.; Barsa, A.S. and Pannu, P.P.S. 1997. Abscisic acid is a potent inhibitor of growth and sporidial formation in Neovosia indica cultures: Dual mode of action via loss of polyamines and cellular turgidity. Phytoparasitica, 25(2): 111-116.

Shaner, G. and Finney, R.E. 1977. The effect of nitrogen fertilization on the expression of slow-mildewing resistance in Knox wheat. Phytopathology, 67: 1051-1056.

Tavakkoli, E.; Fatehi, F.; Oventry, S.; Rengasamy, S. and Glenn, K. 2011. Additive effects of $\mathrm{Na}+$ and $\mathrm{Cl}-$ ions on barley growth under salinity stress. J. Experimental Botany, 62(6): 2189-2203.

Thaler, S.J.; and Bostock, R.M. 2004. Interactions between abscisic-acid mediated and responses and plant resistance to pathogens and insects. Ecol., 85: 48-58.

Ton, J.; Flors, V. and Mauch-Mani, B. 2009 .The multifaceted role of ABA in disease resistance. Trends Plant Sci., 14 (6): 310-317.

Wheeler, B.E.J. 1969. An Introduction to Plant Disease. John Wiley and Sons Limited, London. 301pp.

(Received 29/09/2013; in revised form 30/10/2013)

Egypt. J. Phytopathol., Vol. 41, No. 2 (2013) 


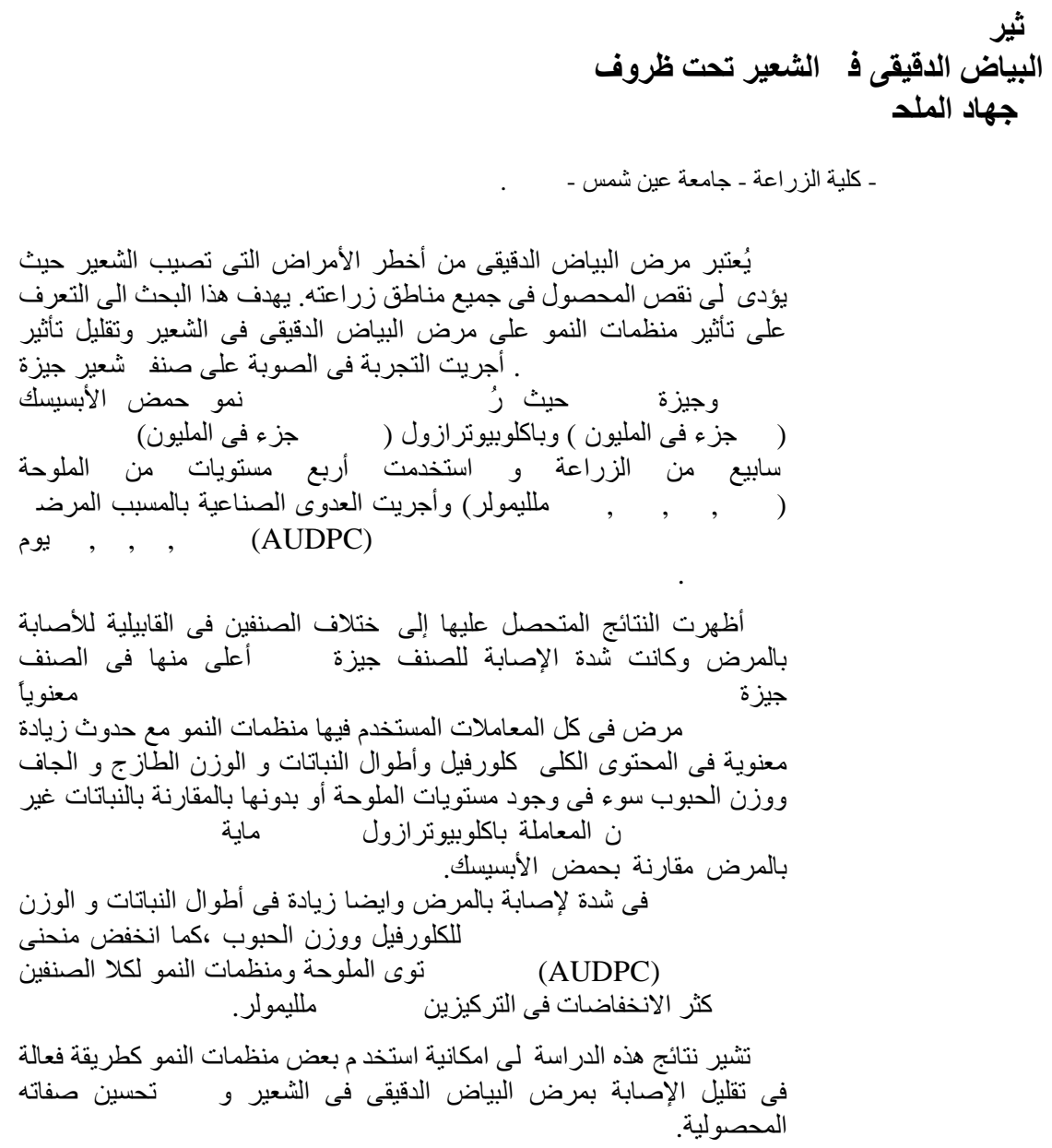

